\title{
Elasticity of Demand in Urban Traffic Case Study: City of Rijeka
}

\author{
Drago Pupavac ${ }^{1 *}$, Robert Maršanić2 ${ }^{2}$ Ljudevit Krpan³ \\ 1 Department of Transport, Polytechnic of Rijeka, Vukovarska 58, 51000 Rijeka, Croatia \\ 2 Department of Transport, Rijeka promet, L.td, Fiumara ul. 13, 51000 Rijeka, Croatia \\ ${ }^{3}$ Department of Regional Development, Infrastructure and Project Management of Primorje-Gorski Kotar County, \\ Adamićeva 14, 51000 Rijeka, Croatia \\ * Corresponding author, e-mail: drago.pupavac@veleri.hr
}

Received: 26 November 2017, Accepted: 31 July 2018, Published online: 28 June 2019

\begin{abstract}
The basic objective of this scientific paper is to explore in both theory and practice the elasticity of demand in urban traffic. We tried to answer whether the elasticity of demand in urban traffic shows a higher intensity of change in the demanded volume of transport services depending on price or income changes. Research results are based on the statistical and mathematical scientific methods. The applicability of the acquired knowledge is tested through a practical research of the elasticity of demand in urban traffic of the city of Rijeka.
\end{abstract}

Keywords

elasticity, demand, urban traffic, prices, income

\section{Introduction}

Elasticity of demand refers to the sensitivity of customers to change in price. If customers are sensitive to price, price reduction will increase the demand for the item and total revenue received. If customers are insensitive to price, that is demand is inelastic, a price reduction will result in a small relative change in demanded quantity and total revenue will fail (Coyle et al., 1994: p.32). Transport activities tend to follow this pattern. When transport prices decline, mobility tends to increase, and if prices increase, mobility declines. Transport price changes can affect trip frequency, route, mode, destination, scheduling, vehicle type, parking location and type of service selected. This information has many practical uses (Ćosić et al., 2017). Planners can use it to predict how demographic and economic trends will affect future travel activity. Policy makers and businesses can predict how fuel tax, parking fee, road toll and transit fare changes would affect travel activities and revenues (www.vtpi.org). For example, in 2003 the mayor of London introduced the congestion-charging zone (CCZ). Motorists would pay up to $\$ 15.20$ to drive to the city center (The Economist, 2017). The introduction of the congestion charge had an immediate impact, reducing the amount of traffic in the heart of the capital by about 15 per cent. About half the drivers who left their cars at home took public transport instead, with the rest getting a lift, using motorbikes or cycles to get to work or avoiding the area altogether. Transport for London (TfL), which administers the scheme, said the overall amount of traffic fell by 21 per cent between 2002 and 2006. The result is that 70,000 fewer vehicles are on the streets every day than before the charge began (Morris, 2008). In general, the demand for freight transportation is inelastic (Pupavac, 2009) and because of that the subject of this research is the elasticity of demand for passenger traffic in urban areas.

\section{Theoretical background}

To understand how prices affect travel decisions, think of all the trips you might make, as illustrated in Fig. 1.

Some trips are very important so you would take them even if their price is high, but others are of lower value and so you will only take them if their price is low. For example, you might shop across town if travel is cheap and convenient, but you will shop locally or online if financial or time costs increase (Litman, 2013).

The elasticity of demand means it is capable of change, depending on the flow of prices or movement of the citizens' income. The demand is elastic when the fall or rise of prices causes substantial increase or reduction of demand, that is, when the rise or fall of income results in the rise or 


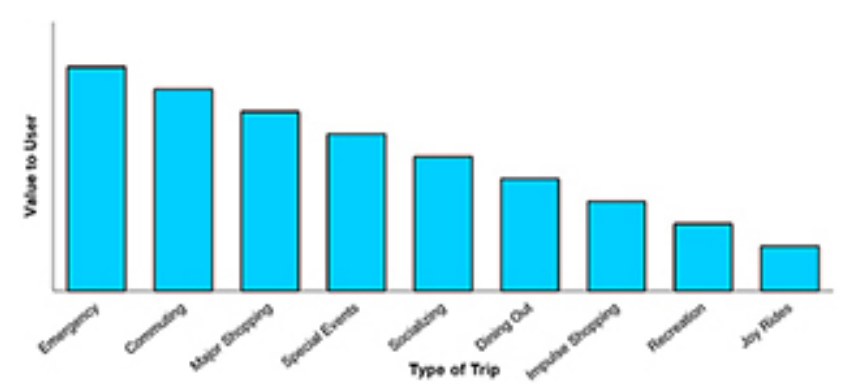

Fig. 1 Travel Ranked by User Value (Victoria Transport Policy Institute, 2002)

fall of demand. Inelastic demand is the one which changes slightly according to the changes in prices or income.

In order to define the level of elasticity, the elasticity coefficient is used, which shows by how much per cent the value of the dependent variable will change if the independent variable changes by $1 \%$. The notion of price elasticity is at the core of transport demand and refers to the variation of demand in response to a variation of cost. For example, an elasticity of -0.5 for vehicle use with respect to vehicle operating costs means that an increase of $1 \%$ in operating costs would imply a $0.5 \%$ reduction in vehicle mileage or trips. Variations of transport costs have different consequences for different modes, but transport demand has a tendency to be inelastic. While commuting tends to be inelastic in terms of costs, it is elastic in terms of time. For economic sectors where freight costs are a small component of the total production costs, variations in transport costs have limited consequences on the demand. For air transportation, especially the tourism sector, price variations have significant impact on demand. Thus there are differences among elasticities of the obtained price, which raises questions about the transferability of the results to other locations and/or other time periods. Hence, each case is characterized by a specific local environment in terms of modal choice options, budget/income of the transport user, spatial planning, price levels, etc. All these factors combined can make the behavior of transport users somewhat different across regions and settings.

Transport demand is a multi-variable function. Many factors can affect travel demands (Litman, 2013): 1) Demographics, 2) Economic Activity, 3) Transport Options, 4) Geography and Land Use Patterns, 5) Demand Management Strategies, 6) Prices (Monetary Costs).

\section{Measuring elasticity}

Price sensitivity is often measured using elasticities, defined as the percentage change in a good's consumption caused by each one-percent change in its price or other characteristics such as travel speed or transit service (Puparac, 2017).

There are several methods used to calculate the elasticity of demand in traffic: 1) point elasticity - takes the elasticity of demand at a particular point on a curve and 2) arc elasticity - measures elasticity at the midpoint between the two selected points.

The formula for point elasticity of demand is:

$\eta=\frac{\% \Delta Q / Q}{\% \Delta P / P}$

Arc elasticity $(\eta)$ is calculated as follows:

1. Arc elasticity

$\eta=\frac{\Delta \log Q}{\Delta \log P}$ or $\eta=\frac{\log Q_{2}-\log Q_{1}}{\log P_{2}-\log P_{1}}$

$P_{2}=P_{1}\left(\frac{Q_{2}}{Q_{1}}\right)^{\frac{1}{\eta}}$ or $Q_{2}=Q_{1}\left(\frac{P_{2}}{P_{1}}\right)^{\eta}$.

Mid-Point Arc Elasticity

$$
\begin{aligned}
& \eta=\left[\frac{\Delta Q}{\frac{1}{2}\left(Q_{1}+Q_{2}\right)}\right]:\left[\frac{\Delta P}{\frac{1}{2}\left(P_{1}+P_{2}\right)}\right] \text { or } \\
& \eta=\frac{\Delta Q}{P_{1}+P_{2}}: \frac{\Delta P}{Q_{1}+Q_{2}} \text { or } \\
& \eta=\frac{\left(Q_{2}-Q_{1}\right)\left(P_{1}+P_{2}\right)}{\left(P_{2}-P_{1}\right)\left(Q_{1}+Q_{2}\right)} . \\
& P_{2}=P_{1} \times\left[\frac{Q_{1}(\eta-1)+Q_{2}(\eta+1)}{Q_{2}(\eta-1)+Q_{1}(\eta+1)}\right] \text { or } \\
& Q_{2}=Q_{1} \times\left[\frac{P_{1}(\eta-1)-P_{2}(\eta+1)}{P_{2}(\eta-1)-P_{1}(\eta+1)}\right]
\end{aligned}
$$

where $\eta$ is the elasticity value, $Q_{1}$ and $Q_{2}$ refer to prior and latter consumption, while $P_{1}$ and $P_{2}$ refer to prior and latter price or service.

Apart from price elasticity, other types of elasticity are defined in order to increase the influence of other determinants of demand (Immers and Stada, 2004).

The cross price elasticity of demand is used to determine the effect of changes in the cost of related goods. Take a product $a$. We want to determine the change in demand for good $a$ when the price of a related product $b$ changes. The cross-price elasticity of $b$ is then defined as follows:

$$
\eta=\frac{\% \text { change in demand for } a}{\% \text { change in price for } b}
$$


The income elasticity of demand shows the influence of a change in income:

$\eta=\frac{\% \text { change in demand } Q}{\% \text { change in income } I}$

Arc income elasticity is calculated as follows:

$\eta=\frac{\Delta Q}{\Delta I} \times \frac{I_{2}+I_{1}}{Q_{2}+Q_{1}}$

We use the word "coefficient" to describe the values for price elasticity of demand $(\eta)$.

- If $(\eta)=\mathbf{0}$ demand is perfectly inelastic - demand does not change at all when the price changes - the demand curve will be vertical.

- If $(\eta)$ is between 0 and 1 (i.e. the \% change in demand from A to B is smaller than the percentage change in price), then demand is inelastic.

- If $(\eta)=\mathbf{1}$ (i.e. the \% change in demand is exactly the same as the $\%$ change in price), then demand is unit elastic. A $5 \%$ rise in price would lead to a $5 \%$ contraction in demand leaving total spending the same at each price level.

- If $(\eta)>\mathbf{1}$, then demand responds more than proportionately to a change in price i.e. demand is elastic. For example if a $15 \%$ increase in the price of a good leads to a $30 \%$ drop in demand. The price elasticity of demand for this price change is -2 .

\section{Research results and discussion}

What follows is the practical example of traffic demand in the City of Rijeka: 1) the elasticity of registered passengers cars depending on the movement of the real GDP and the average petrol price, 2) the elasticity of the number of cars in the city center depending on the movement of the real GDP and the average petrol price, 3) the elasticity of the number of passengers in public bus transport depending on the movement of the real GDP and the average petrol price, 4) the elasticity of demand in parking services depending on the hourly parking price.

1) The elasticity of registered passengers cars depending on the movement of the real GDP and the average petrol price.

In order to calculate the elasticity of registered passengers cars (NRPC) depending on the movement of the real GDP and the average petrol price (PP), the information in Table 1 will be used.

Based on the obtained data, i.e. the calculated elasticity per year, it can be concluded that in periods of economic

Table 1 The point elasticity of registered personal vehicles depending on the movement of the real GDP and the average petrol price Source: Republic of Croatia, Ministry of Internal Affairs, Police administration Primorsko-goranska Rijeka and authors' calculation

\begin{tabular}{|c|c|c|c|c|c|c|c|c|}
\hline Year & NRPC & $\begin{array}{c}\text { GDP (000 HRK at } \\
\text { constant prices 1990) }\end{array}$ & PP & $\begin{array}{l}\% \text { change } \\
\text { NRPC }\end{array}$ & $\begin{array}{l}\% \text { change } \\
\text { GDP }\end{array}$ & $\begin{array}{l}\% \text { change } \\
\text { PP }\end{array}$ & $\mathrm{E}_{\mathrm{nrv} / \mathrm{gdp}}$ & $\mathrm{E}_{\mathrm{nrv} / \mathrm{pp}}$ \\
\hline 1997 & 50241 & $226,346.7$ & 4.12 & & & & & \\
\hline 1998 & 50818 & $231,158.8$ & 3.92 & 1.15 & 2.13 & -4.85 & 0.54 & -0.24 \\
\hline 1999 & 52466 & $227,685.1$ & 4.03 & 3.24 & -1.50 & 2.81 & -2.16 & 1.16 \\
\hline 2000 & 54021 & $234,589.7$ & 5.76 & 2.96 & 3.03 & 42.93 & 0.98 & 0.07 \\
\hline 2001 & 58920 & $243,586.0$ & 6.32 & 9.07 & 3.83 & 9.72 & 2.36 & 0.93 \\
\hline 2002 & 61558 & $256,841.8$ & 6.4 & 4.48 & 5.44 & 1.27 & 0.82 & 3.54 \\
\hline 2003 & 64150 & $269,575.0$ & 6.44 & 4.21 & 4.96 & 0.63 & 0.85 & 6.74 \\
\hline 2004 & 65852 & $281,031.0$ & 6.94 & 2.65 & 4.25 & 7.76 & 0.62 & 0.34 \\
\hline 2005 & 67962 & $292,859.8$ & 7.4 & 3.20 & 4.21 & 6.63 & 0.76 & 0.48 \\
\hline 2006 & 70326 & $306,739.8$ & 7.63 & 3.48 & 4.74 & 3.11 & 0.73 & 1.12 \\
\hline 2007 & 72058 & $323,522.8$ & 7.72 & 2.46 & 5.47 & 1.18 & 0.45 & 2.09 \\
\hline 2008 & 73768 & $331,155.4$ & 8.25 & 2.37 & 2.36 & 6.87 & 1.01 & 0.35 \\
\hline 2009 & 72449 & $308,305.7$ & 7.21 & -1.79 & -6.90 & -12.61 & 0.26 & 0.14 \\
\hline 2010 & 70331 & $301,214.7$ & 8.18 & -2.92 & -2.30 & 13.45 & 1.27 & -0.22 \\
\hline 2011 & 68945 & $301,214.7$ & 10.0 & -1.97 & 0.00 & 22.25 & - & -0.09 \\
\hline 2012 & 63065 & $295,190.4$ & 10.4 & -8.53 & -2.00 & 4.50 & 4.26 & -1.90 \\
\hline 2013 & 61798 & $292,238.5$ & 10.0 & -2.01 & -1.00 & -4.31 & 2.01 & 0.47 \\
\hline 2014 & 61929 & $290,777.3$ & 10.5 & 0.21 & -0.50 & 5.00 & -0.42 & 0.04 \\
\hline 2015 & 62124 & $295,430.0$ & 9.3 & 0.31 & 1.60 & -11.43 & 0.20 & -0.03 \\
\hline
\end{tabular}


growth the number of registered vehicles depends more on the GDP than the price of petrol. As the global economic crisis in 2008 had a serious impact on Croatian economy, the elasticity of income and price will be calculated for the period before the crisis (1997-2008) and the one after the crisis (2008-2015).

The elasticity of income in the number of registered personal vehicles depending on the real GDP has been calculated using Eq. (7).

The elasticity of income in the period before the crisis (1997-2008) is $\eta=1.01$, which means that if in the interval between HRK 226,346.7 and 331,155.4 the real GDP increases by $1 \%$, the number of registered personal vehicles grows in average by $1.01 \%$, but only if other variables remain unchanged. This confirms the existence of unit elasticity between the GDP movement and the number of registered private vehicles in the given period.

The elasticity of income in the post-crisis period (2008$2015)$ is $\eta=1.5$, which means that if in the interval between HRK 331,155.4 and 295,430.0 the real GDP decreases by $1 \%$, the number of registered personal vehicles lessens by $0.16 \%$, but only if other variables remain unchanged.

The elasticity of price in the pre-crisis period (19972008) is $\eta=0.16$, which means that the $1 \%$ increase in petrol price from the interval $(4.12,8.25)$ is in line with average $0.16 \%$ increase in number of registered vehicles and vice versa. Thus, the number of registered personal vehicles in the given period is showing great elasticity in relation to petrol price.

2) The elasticity of the number of vehicles in the city center depending on the movement of the real GDP and the average petrol price.

Average daily and monthly traffic flow in the city center has been on a significant decline since 2009 , i.e. in the

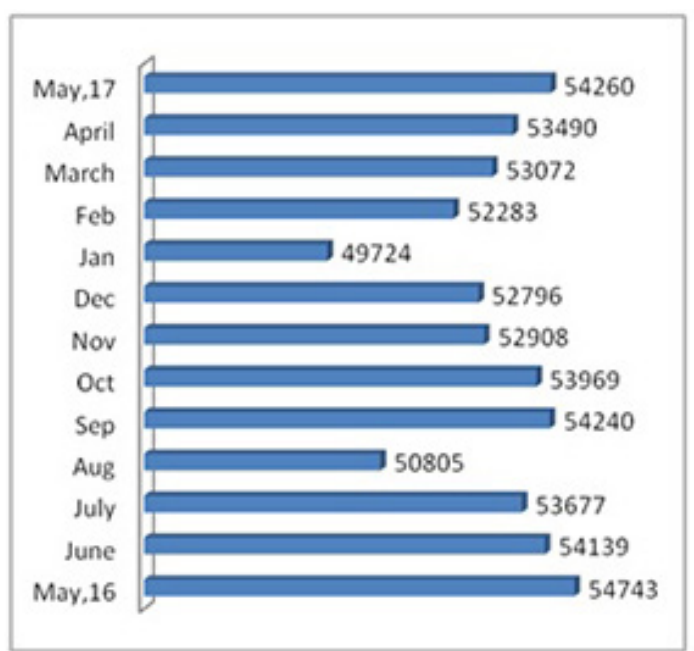

Fig. 2 Average daily traffic in Rijeka city centre, monthly from May 2016 to May 2017 (Source: Rijeka promet L.td. transport department)

period of recession in Croatian economy. According to the latest data, average daily traffic in the city of Rijeka is never more than 55 thousand vehicles (cf. Fig. 2).

Decrease of the average number of vehicles in Rijeka city center is directly related to the GDP movement and the average petrol price. Accordingly, what follows is the calculation of elasticities of income and price of the average number of vehicles in the city center for the period between 2008 and 2016. The elasticity of income of the average number of vehicles passing through the city center is shown in Table 2.

Arc value of the elasticity of income in the given period is $\eta=1.63$. The calculated value shows that a GDP decrease of $1 \%$ from the interval $(331,155.4303,997.5)$ is in line with the lessening of $1.63 \%$ in the average daily traffic per month in the city center and vice versa.

The elasticity of price in the average number of vehicles in the city center is shown in Table 3.

Table 2 The point elasticity of the average number of vehicles passing through the city centre in relation to the real GDP movement (Source: Republic of Croatia, Ministry of Internal Affairs, Police administration Primorsko-goranska Rijeka and authors' calculation)

\begin{tabular}{|c|c|c|c|c|c|}
\hline Year & AMNVC & GDP & $\%$ Change AMNVC & $\%$ Change GDP & $\mathrm{E}_{\text {amnvc/gdp }}$ \\
\hline 2008 & 61114 & $331,155.41$ & & & \\
\hline 2009 & 64065 & $308,305.68$ & 4.83 & -6.90 & -0.70 \\
\hline 2010 & 56080 & $301,214.65$ & -12.46 & -2.30 & 5.42 \\
\hline 2011 & 53995 & $301,214.65$ & -3.72 & 0.00 & 0.00 \\
\hline 2012 & 54336 & $295,190.36$ & 0.63 & -2.00 & -0.32 \\
\hline 2013 & 55522 & $292,238.45$ & 2.18 & -1.00 & -2.18 \\
\hline 2014 & 53766 & $290,777.26$ & -3.16 & -0.50 & 6.33 \\
\hline 2015 & 54125 & $295,430.00$ & 0.67 & 1.60 & 0.42 \\
\hline 2016 & 53134 & $303,997.47$ & -1.83 & 2.90 & -0.63 \\
\hline
\end{tabular}


Table 3 Elasticity of the average number of vehicles in the city centre in relation to the movement in the average petrol price (Source: Republic of Croatia, Ministry of Internal Affairs, Police administration Primorsko-goranska Rijeka, INA-MOL and authors' calculation)

\begin{tabular}{lcccrc}
\hline Year & AMNVC & PP & \% Change AMNVC & \% Change PP & $\mathrm{E}_{\text {amnvc/pp }}$ \\
\hline 2008 & 61114 & 8.25 & & & \\
2009 & 64065 & 7.21 & 4.83 & -12.61 & -0.38 \\
2010 & 56080 & 8.18 & -12.46 & 13.45 & -0.93 \\
2011 & 53995 & 10.00 & -3.72 & 22.25 & -0.17 \\
2012 & 54336 & 10.45 & 0.63 & 4.50 & 0.14 \\
2013 & 55522 & 10.00 & 2.18 & -4.31 & -0.51 \\
2014 & 53766 & 10.50 & -3.16 & -11.43 & -0.63 \\
2015 & 54125 & 9.30 & 0.67 & 2.15 & -0.06 \\
2016 & 53134 & 9.50 & -1.83 & -0.85 \\
\hline
\end{tabular}

Arc value of the elasticity of price in the given period is $\eta=-0.86$. The calculated value shows that the increase in petrol prices by $1 \%$ from the interval $(8.25,9.5)$ is in line with the lessening of $0.86 \%$ in the daily traffic per month in the city center and vice versa.

Accordingly, it can be concluded that in the period from 2008 to 2016 the elasticity of the average number of vehicles passing through the city center has increased in relation to changes in income rather than to changes in petrol price.

3) The elasticity of the number of passengers in public bus transport depending on the movement of the real GDP and the average petrol price.

Usage of public transport in any form affects numerous problems caused by personal vehicles. The city of Rijeka is one of Croatian cities with the greatest number of public transport users (cf. Table 4).

According to data shown in Table 4, the city of Rijeka has the highest ratio between the number of passengers and the number of residents (205), which confirms a rather good management of public transport in Rijeka. What follows is the calculation of elasticity in income and price of the number of passengers in public transport between 2008 and 2016.

Arc value of elasticity of income in the number of passengers for the given period is -0.033 . This shows that the $1 \%$ GDP decrease from the interval $(331,155.4303,997.5)$ is in line with the $0.033 \%$ decrease in the number of passengers in public transport, which means that there is no elasticity between the movement of GDP and the number of passengers in public transport within the given period.

Arc value of elasticity of income in the number of passengers for the given period is 1.34 . The calculated value shows that the $1 \%$ increase in the average petrol price from the interval $(8.25,9.5)$ is in line with the $1.34 \%$
Table 4 Number of passengers in urban public transport, 2015 (Source: Transport and Communication, 2015 Statistical Reports 2016, Zagreb)

\begin{tabular}{lccc}
\hline City & $\begin{array}{c}\text { Passengers carried } \\
(\mathrm{pc})\end{array}$ & $\begin{array}{c}\text { Population } \\
(\mathrm{pop})\end{array}$ & $\begin{array}{c}\text { Ratio } \\
\mathrm{pc} / \mathrm{pop}\end{array}$ \\
\hline Dubrovnik & 9500000 & 64000 & 148.44 \\
Split & 36000000 & 312300 & 115.27 \\
Šibenik & 3660000 & 81200 & 45.07 \\
Zadar & 8325000 & 105150 & 79.17 \\
Rijeka & 43500000 & 212000 & 205.19 \\
Pula & 3600000 & 80000 & 45.00 \\
Zagreb & $2.84 \mathrm{E}+08$ & 926000 & 306.72 \\
Sisak & 1400000 & 53800 & 26.02 \\
Osijek & 10300000 & 100000 & 103.00 \\
Total & 400311000 & 1934450 & 206.94 \\
\hline
\end{tabular}

increase in the number of passengers in public transport. The obtained data suggests that in conditions of growth of the average petrol price, there is a larger number of passengers who will use public transport and vice versa. Reducing the cost of personal vehicles usage will result in reduction in use of public transport, walking or cycling. This is one of the reasons cited by Klein (2014) which gave way to the following conclusion: "Rather than allowing an increase in price of bus and subway transport, with simultaneous degradation in quality of services, we should lower the prices and expand the range of services - regardless of the cost."

4) The elasticity of demand in parking services depending on the hourly parking price.

Several factors converge to increase the parking rates in central business districts (Rodrigue et al., 2006): a) the lack of space, b) demand for parking space and c) regulatory constraints. London is at the very top of the list of the most expensive places to park a vehicle (cf. Fig. 3). 
Table 5 Elasticity of the number of passengers in public transport in relation to the movement of the real GDP (Source: Autotrolej L.td. and authors' calculation)

\begin{tabular}{|c|c|c|c|c|c|c|c|c|}
\hline Year & $\begin{array}{c}\text { Number of passengers } \\
\text { (NP) }(000)\end{array}$ & GDP & PP & $\begin{array}{l}\text { \% Change } \\
\text { NP }\end{array}$ & $\begin{array}{l}\% \text { Change } \\
\text { GDP }\end{array}$ & $\begin{array}{c}\text { \% Change } \\
\text { PP }\end{array}$ & $\mathrm{E}_{\mathrm{np} / \mathrm{gdp}}$ & $\mathrm{E}_{\mathrm{np} / \mathrm{pp}}$ \\
\hline 2008 & 35025.2 & $331,155.41$ & 8.25 & & & & & \\
\hline 2009 & 33653.8 & $308,305.68$ & 7.21 & -3.92 & -6.90 & -12.61 & 0.57 & 0.31 \\
\hline 2010 & 40887.5 & $301,214.65$ & 8.18 & 21.49 & -2.30 & 13.45 & -9.35 & 1.60 \\
\hline 2011 & 46129.5 & $301,214.65$ & 10.00 & 12.82 & 0.00 & 22.25 & na & 0.58 \\
\hline 2012 & 45341.5 & $295,190.36$ & 10.40 & -1.71 & -2.00 & 4.50 & 0.85 & -0.38 \\
\hline 2013 & 45656.8 & $292,238.45$ & 10.00 & 0.70 & -1.00 & -4.31 & -0.70 & -0.16 \\
\hline 2014 & 41259.2 & $290,777.26$ & 10.50 & -9.63 & -0.50 & 5.00 & 19.26 & -1.93 \\
\hline 2015 & 43122.9 & $295,430.00$ & 9.30 & 4.52 & 1.60 & -11.43 & 2.82 & -0.40 \\
\hline 2016 & 42348.7 & $303,997.50$ & 9.50 & -1.80 & 2.90 & 2.15 & -0.62 & -0.83 \\
\hline
\end{tabular}

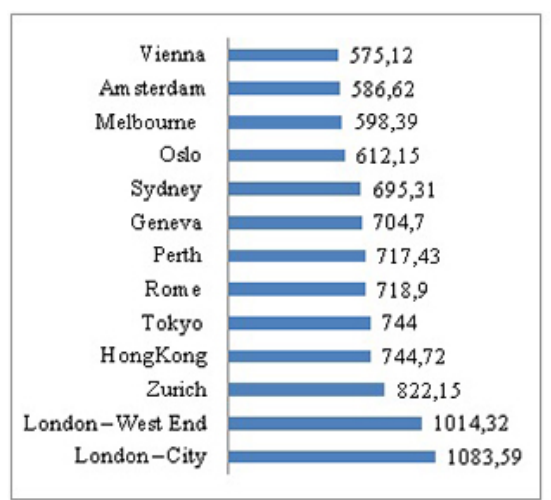

Fig. 3 Top Cities by Monthly Parking rates, 2011 (USD) (Source: prepared by the authors according to Colliers International, Parking Rate Survey, Global 2011.)

Monthly parking rates in the City (London's financial district) topped the global list at $\$ 1,084.00$ USD per month followed by the West End at \$1,014.00 USD. Cities with low parking rates not only fail to make better revenues from parking lots, but create a traffic system based on personal vehicles, thus causing larger economic, social and environmental costs (Maršanić, 2012). For example, the decision of city authorities in Rijeka to increase the price of parking in the city, or the decision to extend the zero parking zone to the first zone, has resulted in a significant increase in revenue from parking lots. This was decided at the end of February 2012, and since has brought an increase in revenues of HRK 1,067 million or $6 \%$ in relation to 2011 . Non-elasticity of demand for parking services in the city of Rijeka does little to encourage local businesses involved in providing parking services to work on a more active pricing policy. Only one of the companies providing parking services has a lower hourly cost, and this after 16 o'clock when the bid.

\section{Conclusion}

Traffic demand represents the total demand for transport or transfer services of different entities (people, goods, packages, information), different types of traffic at a defined price within a given time period. The elasticity of traffic demand in relation to the change in its depending factors is defined as the ratio of their relative changes. This value, the so-called coefficient of elasticity, shows by how many percentages traffic demand would change if the observed factor changes by one per cent observed on a certain level. Such analytical procedure provides significant information and is the basis for exploring the possibility of impact on the movement of traffic demand. Accordingly, using the practical example of the city of Rijeka, this paper has explored: 1) the elasticity of registered personal vehicles depending on the movement of the real GDP and the average petrol price, 2) the elasticity of the number of cars in the city center depending on the movement of the real GDP and the average petrol price, 3) the elasticity of the number of passengers in public bus transport depending on the movement of the real GDP and the average petrol price, 4) the elasticity of demand in parking services depending on the hourly parking price.

Research results indicate the existence of unit elasticity between the movement of GDP and the number of registered personal vehicles in the pre-crisis period and the existence of greater elasticity in the crisis period with the coefficient of $\eta=1.5$. The number of registered personal vehicles in the pre-crisis period was non-elastic $(\eta=0.16)$ in relation to the movement of petrol price, while the elasticity was established during the crisis, and this with the coefficient of $\eta=1.43$. Movement of the average number of vehicles entering the city center in the period from 
2008 to 2016, there was greater elasticity depending on changes in income $(\eta=1.63)$ than changes in petrol price $(\eta=0.86)$. The number of passengers in public transport of Rijeka for the same period shows a total non-elasticity

\section{References}

Moore, R. J. (2011) "Parking Rate Survey, Global", [pdf] Colliers International, Available at: http:/www.cincinnaticolliers.com/ sharedfiles/721201041035.pdf [Accessed: 10 June 2017]

Ćosić, M., Šimunović, Lj., Šojat, D. (2017) "Price Elasticity in Public Transport - A Case Study of the City of Zagreb", In: International Conference on Traffic Development, Logistic and Sustainable Transport - ZIRP 2017, Zagreb, Croatia, pp. 71-79. [online] Available at: http://www.fpz.unizg.hr/zirp-lst/assets/files/ZIRP2017-conference-proceedings.pdf [Accessed: 11 October 2017]

Coyle, J., Bardi, E., Novack, R. (1994) "Transportation", West Publishing Company, St. Paul/Minneapolis, USA

The Economist (2017) "How and why road-pricing will happen", The Economist, [online] 3 August. Available at: https://www.economist.com/international/2017/08/03/how-and-why-road-pricingwill-happen [Accessed: 12 September 2017]

Morris, N. (2008) "The Big Question: Has the congestion charge been effective in reducing London's traffic", Independent, [online] 13 February. Available at: https:/www.independent.co.uk/ news/uk/home-news/the-big-question-has-the-congestioncharge-been-effective-in-reducing-londons-traffic-781505.html [Accessed: 17 May 2017]

Immers, L. H., Stada, J. E. (2004) "Basics of Transport Economics", Katholieke Universiteit Leuven. in relation to the movement of GDP and elasticity compared to the average increase in petrol price $(\eta=1.34)$. The results also indicate non-elasticity of demand for parking services in the city of Rijeka.

Klein, N. (2014) "This Changes Everything: Capitalisam vs. The Climate", Simon \& Schuster, New York, USA.

Litman, T. A. (2013) "Understanding Transport Demands and Elasticities - How Prices and Other Factors Affect Travel Behavior", Victoria Transport Policy Institute, [pdf] Available at: http://www.vtpi.org/ elasticities.pdf [Accessed: 31 July 2017]

Maršanić, R. (2012) "Kultura parkiranja" (Culture of Parking), IQ plus, Rijeka, Croatia. (in Croatian)

Pupavac, D. (2009) "Načela ekonomike prometa" (Priciples of Transport Economics), Polytechnic of Rijeka, Rijeka, Croatia. (in Croatian)

Pupavac, D. (2017) "Prometna ponuda i prometna potražnja" (Transport Supply and Demand), Polytechnic of Rijeka, Rijeka, Croatia. (in Croatian)

Frka, D. (2017) "Traffic counting in urban centre of Rijeka". [internal documentation] Rijeka promet, L.td.

Rodrigue, J.P., Comtois, C., Slack, B. (2006) "The Geography of Transport Systems", Routledge, London and New York.

Victoria Transport Policy Institute (2002) "Transportation Elasticities", [online] Available at: http://www.vtpi.org/tdm/tdm11.htm [Accessed: 27 July 2017] 